http://dx.doi.org/10.18778/1429-3730.50.05

\author{
dr Dorota Michalak*
}

\title{
PRAKTYCZNY WYMIAR OPIEKUŃCZEJ ROLI PAŃSTWA - DOMY DZIENNEGO POBYTU
}

\author{
THE PRACTICAL DIMENSION OF THE CARING ROLE OF THE STATE \\ - HOUSES OF DAILY STAY
}

\begin{abstract}
One of the forms of state aid to the elderly are the Department of Social Welfare, which provide services living, care, support and education. Those Department, which provide only daycare called Day Care Houses. The purpose of this article is to determine the need and extent of the availability of Day Care Homes, the degree of satisfaction of the needs and expectations of people attending to them and to present the principles of their financing. In order to do this simple-depth interview with an employee of the Social Welfare Centre in Lodz, employed as a Senior Inspector (Planning Department) and a survey of 96 residents of houses Day Centre in Lodz. As is clear from the survey conducted willing people do not have to wait long for the opportunity to use the Day Care Homes in Lodz. Research verifies the functionality of the described institution, which is in line with the law on social assistance and underlines the importance of institutions and helps older people in everyday life, prevents the feeling of uselessness and social exclusion.
\end{abstract}

Keywords: social assistance, social care services

JEL classification: E02

* Uniwersytet Łódzki, Instytut Ekonomii, Katedra Ekonomii Rozwoju; d.michalak@uni.lodz.pl 


\section{Wprowadzenie}

Cechą charakterystyczną województwa łódzkiego jest wiekowa struktura ludności. Jak wskazują dane GUS, ponad $18 \%$ społeczeństwa to osoby w wieku poprodukcyjnym, co stawia region łódzki na pierwszym miejscu w kraju. W latach 2010-2035 liczba ludności w wieku 65 lat i więcej wzrośnie o 170 tys., czyli o 45\%. Analizując powyższe dane, można stwierdzić, że proces starzenia się ludności jest i będzie zjawiskiem nieuniknionym. Takie zjawiska jak: wzrost liczby najstarszych (80 plus), feminizacja starości ${ }^{1}$, pauperyzacja starości ${ }^{2}$, zmiany w systemie emerytalnym, wzrost liczby osób bez uprawnień do świadczeń emerytalnych, konieczność zapewnienia seniorom zajęcia, wzrost ich aspiracji, wymagać będą odpowiednich działań ze strony instytucji publicznych ${ }^{3}$.

Domy pomocy społecznej (DPS) stanowią tradycyjną formę tzw. pomocy instytucjonalnej. Jak wskazuje Ustawa z dnia 12 marca 2004 r. o pomocy społecznej (tj. Dz.U. z 2013 r., poz. 182 z późn. zm.), osobie wymagającej całodobowej opieki z powodu wieku, choroby lub niepełnosprawności, niemogącej samodzielnie funkcjonować w codziennym życiu, której nie można zapewnić niezbędnej pomocy w formie usług opiekuńczych ${ }^{4}$, przysługuje prawo do umieszczenia $\mathrm{w}$ domu pomocy społecznej. Inną formą pomocy są domy dziennego pobytu (DDP), które zapewniają osobom starszym opiekę dzienną.

Zadaniem niniejszego artykułu jest określenie zapotrzebowania i stopnia dostępności domów dziennego pobytu, stopnia zaspokajania potrzeb i oczekiwań osób do nich uczęszczających oraz przedstawienie zasad ich finansowania. W tym celu przeprowadzono prosty wywiad pogłębiony z pracownikiem Miejskiego Ośrodka Pomocy Społecznej w Łodzi zatrudnionym na stanowisku starszego inspektora (Dział Planowania) oraz ankietę wśród 96 pensjonariuszy domów dziennego pobytu w Łodzi.

\footnotetext{
${ }^{1}$ W województwie łódzkim zdecydowana większość osób starszych to kobiety.

2 Pauperyzacja to proces społeczny polegający na obniżaniu się stopy życiowej jednostek lub zbiorowości.

${ }^{3}$ P. Szukalski, Starzenie się ludności Łodzi i województwa łódzkiego w nadchodzacych dekadach, [w:] Aktywizacja osób starszych w województwie tódzkim, Regionalne Centrum Polityki Społecznej, PAG-Uniconsult, Łódź 2011, s. 10, 19-20.

${ }^{4}$ Usługi opiekuńcze - rodzaj pomocy świadczonej często przez gminę, instytucję pomocy społecznej lub inną instytucję działającą na rzecz osób wymagających takiej pomocy. Usługi opiekuńcze obejmują pomoc w zaspokajaniu codziennych potrzeb życiowych, opiekę higieniczną, zaleconą przez lekarza pielęgnację oraz, w miarę możliwości, zapewnienie kontaktów z otoczeniem.
} 


\section{Cel dzialalności domów dziennego pobytu}

Artykuł 55 ustawy o pomocy społecznej mówi, że dom pomocy społecznej świadczy usługi bytowe, opiekuńcze, wspomagające i edukacyjne na poziomie obowiązującego standardu, w zakresie i formach wynikających $\mathrm{z}$ indywidualnych potrzeb osób przebywających w danej placówce.

Do usług bytowych zalicza się miejsce zamieszkania, wyżywienie, odzież i obuwie oraz utrzymanie czystości. Usługi opiekuńcze polegają na udzielaniu pomocy w podstawowych czynnościach życiowych, pielęgnacji oraz niezbędnej pomocy w załatwianiu spraw osobistych. Wśród usług wspomagający znajduje się natomiast umożliwianie udziału w terapii zajęciowej, podnoszenie sprawności i aktywizacji społecznej, umożliwianie zaspokajania potrzeb religijnych i kulturowych, stymulowanie nawiązywania i rozwijania kontaktu z rodziną i środowiskiem oraz działanie zmierzające do usamodzielnienia ${ }^{5}$.

Domy pomocy społecznej działają na podstawie:

- ustawy o pomocy społecznej - art. 54-66;

- Rozporządzenia Ministra Pracy i Polityki Społecznej z dnia 23 sierpnia 2012 r. w sprawie domów pomocy społecznej (Dz.U. z 2012 r., poz. 964);

- Ustawy z dnia 19 sierpnia 1994 r. o ochronie zdrowia psychicznego (Dz.U. z 2011 r. Nr 231, poz. 1375 z późn. zm.).

Domy pomocy społecznej, w zależności od tego, dla kogo są przeznaczone, dzielą się na domy dla:

- osób w podeszłym wieku,

- osób przewlekle somatycznie chorych,

- osób przewlekle psychicznie chorych,

- dorosłych niepełnosprawnie intelektualnie,

- dzieci i młodzieży niepełnosprawnych intelektualnie,

- osób niepełnosprawnych fizycznie ${ }^{6}$.

W celu ustalenia indywidualnych potrzeb podopiecznego oraz zakresu świadczonych usług DPS-y organizują zespoły terapeutyczno-opiekuńcze, składające się głównie pracowników placówki?

Liczba miejsc $\mathrm{w}$ domach pomocy społecznej z reguły bywa ograniczona. W przypadku domów z bezpłatnym pobytem o przyjęciu decyduje wywiad środowiskowy, podczas którego urzędnik ocenia ogólną sytuację życiową i materialną kandydata.

${ }^{5}$ A.M. Kruk, Instytucje społeczne. Organizacja, zarzadzanie, wybrane aspekty prawne i gospodarcze, Wydawnictwo Akademii Pedagogiki Specjalnej, Warszawa 2010, s. 84.

${ }^{6}$ Ustawa o pomocy społecznej.

${ }^{7}$ Rozporządzenia Ministra Pracy i Polityki Społecznej z dnia 23 sierpnia 2012 r. w sprawie domów pomocy społecznej, pkt. 2-4. 
Dom pomocy społecznej może również świadczyć usługi opiekuńcze oraz specjalistyczne usługi opiekuńcze dla osób w nich niezamieszkujących ${ }^{8}$. Domy takie noszą nazwę domów dziennego pobytu. Główną ich funkcją jest pomoc osobom w wieku poprodukcyjnym, które nie pracują zawodowo: emerytom i rencistom, a także niepełnosprawnym i chorym. Celem DDP-ów jest aktywizacja społeczna osób starszych, samotnych oraz chorych (organizacja czasu w ciągu dnia - zaspokajanie potrzeb towarzyskich i kulturowych seniorów, dbałość o ich kondycję fizyczną i psychiczną) oraz zapewnienie wyżywienia.

Domy dziennego pobytu działają jako placówki prywatne lub w ramach działalności ośrodków pomocy społecznej. W tym drugim przypadku usługi ośrodków są bezpłatne, podopieczny pokrywa jedynie koszty wyżywienia oraz ewentualne koszty zajęć dodatkowych, takich jak wycieczki, wyjścia do kina lub teatru.

Zgodnie z przepisami artykułu 51 ustawy o pomocy społecznej dzienne domy pomocy są ośrodkami wsparcia - formą organizacyjną pomocy społecznej dziennego pobytu. Ośrodkami wsparcia są także środowiskowe domy samopomocy, domy dla matek z małoletnimi dziećmi i kobiet w ciąży, schronienia i domy dla bezdomnych oraz kluby samopomocy 9 .

\section{Domy dziennego pobytu w Lodzi - statystyki i źródła finansowania}

Na terenie Łodzi działa 19 domów dziennego pobytu podlegających bezpośrednio pod MOPS lub prowadzących księgowość nadzorowaną przez MOPS. Uczęszcza do nich $826^{10}$ pensjonariuszy. Średniomiesięczny koszt utrzymania jednej osoby w DDP w 2015 roku to $679 \mathrm{zł}$. W roku $2015 \mathrm{w}$ strukturze poniesionych wydatków ogółem (ponad 6,7 mln zł) 59,5\% stanowiły wynagrodzenia wraz z pochodnymi. Ponadto w Łodzi działają jeszcze dwa domy dziennego pobytu prowadzone przez Caritas w ramach współpracy MOPS z organizacjami pozarządowymi ${ }^{11}$.

Podstawę prawną działania domów dziennego pobytu w Łodzi stanowi wspomniana wyżej ustawa o pomocy społecznej, uchwała Rady Miejskiej w Łodzi z dnia 7 września 2005 roku w sprawie organizacji oraz szczególnych zasad ponoszenia odpowiedzialności za pobyt w ośrodkach wsparcia i mieszkaniach

\footnotetext{
${ }^{8}$ Ustawa o pomocy społecznej z dnia 12 marca 2004 roku, Dziennik Ustaw 115, art. 56.

${ }^{9}$ A. Antosz, M. Wasiak, Kierownicy Domów Dziennego Pobytu, [w:] Aktywizacja osób starszych $w$ województwie łódzkim, Regionalne Centrum Polityki Społecznej, PAG-Uniconsult, Łódź 2011, s. 50.

${ }^{10}$ Podana liczba pensjonariuszy dotyczy 2015 roku. W 2014 roku było to 834 , w $2013-832$, a w $2012-855$. Planowa liczba miejsc to 830 .

${ }^{11}$ Na podstawie wywiadu z pracownikiem Działu Planowania MOPS w Łodzi.
} 
chronionych oraz regulaminy organizacyjne domów dziennego pobytu, stanowiące załączniki do zarządzeń dyrektora Miejskiego Ośrodka Pomocy Społecznej w Łodzi ${ }^{12}$.

Polskie przepisy prawne ani prawo lokalne w Łodzi nie określają standardów dotyczących ośrodków wsparcia dla osób starszych. Wielkość placówki, warunki, jej wyposażenie oraz liczba zatrudnionych pracowników wynikają wyłącznie ze zdiagnozowanych potrzeb społecznych i możliwości finansowania budżetu miasta. Techniczne warunki ustalone są na podstawie ogólnych przepisów przeciwpożarowych oraz regulacji dotyczących zbiorowego żywienia (wymogi stacji sanitarno-epidemiologicznej) $)^{13}$.

Działalność domów dziennego pobytu finansowana jest ze środków własnych gminy. Co roku ustalany jest plan wydatków dla każdego DDP, który wskazuje ustalenia dotyczące wysokości i przeznaczenia otrzymanych środków. Ponadto DDP współpracują z podmiotami sektora publicznego, takimi jak jednostki pomocnicze gminy (rada osiedla), szkoły, przedszkola, domy kultury i biblioteki.

Szesnaście domów dziennego pobytu bezpośrednio podlega Wydziałowi Pracy Środowiskowej (WPŚ, w Łodzi są trzy wydziały - Górna, Bałuty i Widzew), które natomiast odpowiadają przed Miejskim Ośrodkiem Pomocy Społecznej (MOPS). Główną różnicą między tymi domami a pozostałymi trzema jest sposób rozliczania się z MOPS - w przypadku większości księgowość prowadzi bezpośrednio MOPS, w pozostałych trzech jest to księgowość własna nadzorowana przez MOPS.

Łączna liczba etatów kalkulacyjnych we wszystkich DDP w Łodzi to 102. W każdym DDP zatrudnionych jest od 5 do 6 pracowników. Liczba ta uzależniona jest od wielkości placówki i liczby pensjonariuszy ${ }^{14}$. Domem dziennego pobytu zarządza administrator, pozostałe stanowiska to: szef kuchni, magazynier, pomoc kuchni oraz pomoc gospodarcza. Pracownicy zatrudnieni są na umowę o pracę, W większości na pełen etat ${ }^{15}$.

Jak wskazuje regulamin organizacyjny domu dziennego pobytu, jest to instytucja zapewniająca pomoc osobom w wieku poprodukcyjnym, niepodejmującym zatrudnienia, niepracującym emerytom i rencistom oraz niepracującym osobom niepełnosprawnym w organizacji czasu wolnego i aktywizacji społecznej. Głównym celem działalności DDP jest zapewnienie wsparcia seniorom oraz kompensowanie skutków samotności, niesamodzielności i niepełnosprawności przez ${ }^{16}$ :

${ }^{12}$ A. Antosz, M. Wasiak, Kierownicy Domów..., s. 50.

${ }^{13}$ Ibidem, s. 50.

${ }^{14}$ Największy DDP w Łodzi znajduje się na ul. Narutowicza 37. Planowa liczba miejsc w tym domu to 70 .

${ }^{15} \mathrm{Na}$ podstawie wywiadu z pracownikiem Działu Planowania MOPS w Łodzi.

${ }^{16}$ Na podstawie Regulaminu Organizacyjnego Domu Dziennego Pobytu w Łodzi. 
- umożliwienie pobytu i wypoczynku na terenie domu,

- zaspokajanie potrzeb towarzyskich i kulturowych,

- uczestnictwo w zajęciach służących utrzymaniu sprawności psychofizycznej,

- zapewnienie całodziennego wyżywienia.

Aby realizować wyżej wymienione cele, DDP świadczy usługi socjalne (w tym zapewnienie minimum jednego ciepłego posiłku), edukacyjne, kulturowo-oświatowe, terapii zajęciowej, organizuje aktywność sportowo-rekreacyjną oraz aktywizuje społecznie pensjonariuszy.

Jak już wspomniano, podstawą przyjęcia pensjonariusza jest rodzinny wywiad środowiskowy przeprowadzany przez pracownika socjalnego. Podczas wywiadu pracownik MOPS zadaje pytania zawarte w kwestionariuszu wywiadu, który zawiera pytania dotyczące przyczyny występowania z wnioskiem o udzielenie pomocy i ma za zadanie określić, z jakim problemem społecznym dana osoba sobie nie radzi. Osoby starsze najczęściej zgłaszają problem samotności, długą lub ciężką chorobę, niepełnosprawność, a także bezradność w czynnościach życia codziennego.

$\mathrm{Na}$ podstawie tego wywiadu wydawana jest decyzja o przyjęciu bądź nieprzyjęciu danej osoby do DDP. Decyzja jest również dokumentem, który wskazuje opłatę, jaką pensjonariusz jest zobowiązany płacić za możliwość uczęszczania do domu dziennego pobytu. Stawka dla pensjonariusza ustalana jest przez Radę Miasta Łodzi na wniosek Rady Domu. Wysokość dziennej stawki żywieniowej ustala kierownik Wydziału Pracy Środowiskowej, pod który podlega dana placówka, w porozumieniu z administratorem, w oparciu o aktualne ceny artykułów żywnościowych oraz obowiązujące normy żywnościowe. Od stycznia 2013 roku stawka jest ujednolicona (taka sama dla każdego domu i pensjonariusza) i wynosi 9,50 zł za dzień (przed rokiem 2013 - 8,50 zł). Wyjątek stanowią osoby w ciężkiej sytuacji, w ich przypadku opłata jest zmniejszana lub nie występuje ${ }^{17}$.

Opłata, którą uiszcza pensjonariusz, traktowana jest jako dochód budżetu państwa, jednak w praktyce jest to tzw. wkład do kotła - zakup artykułów spożywczych. Z środków gminnych natomiast finansowane są wszystkie koszty związane z funkcjonowaniem placówki (wynagrodzenia z pochodnymi, czynsz i inne opłaty, naprawy, środki czystości, podatek od nieruchomości itp.).

\footnotetext{
${ }^{17}$ Na podstawie wywiadu z pracownikiem Działu Planowania MOPS w Łodzi.
} 


\section{Program „Senior-Wigor”}

Program Ministerstwa Rodziny, Pracy i Polityki społecznej (MRPiPS) „Senior-Wigor" obejmuje lata 2015-2020 i jest adresowany do samorządów z niskimi dochodami lub wysokim odsetkiem seniorów w populacji ogółem lub brakiem infrastruktury pomocy społecznej służącej do realizacji usług opiekuńczych adresowanych do osób 60 plus. W ramach programu gminy mogą ubiegać się o środki na dofinansowanie utworzenia domu dziennego pobytu lub modernizację istniejącej placówki. MRPiPS dofinansowuje $80 \%$ wartości zadania, pozostałą części płaci samorząd. Dodatkowo gmina może ubiegać się także o dofinansowanie utrzymania domu. Na program w latach 2015-2020 przeznaczone jest $370 \mathrm{mln}$ zł, z tego $30 \mathrm{mln}$ zł w $2015 \mathrm{roku}^{18}$.

W ramach wyżej wymienionego programu łódzki samorząd otrzymał ponad 155 tys. zł dofinansowania na przekształcenie jednego z domów dziennego pobytu w dom „Senior-Wigor” (co nastąpiło 28 grudnia 2015 roku). Wkład własny gminy wynosił $20 \%-38,5$ tys. zł. Otrzymane fundusze pozwoliły dostosować budynek do potrzeb osób niepełnosprawnych, doposażyć i wyremontować wnętrze domu oraz wyodrębnić dodatkową salę do ćwiczeń rehabilitacyjno-ruchowych i zajęć z komputerem (31\% ogólnych zakupów stanowił sprzęt rehabilitacyjny) ${ }^{19}$.

Cele zmodernizowanego domu, w porównaniu z poprzednią formą, zostały rozszerzone o następujące punkty ${ }^{20}$ :

- przeciwdziałanie izolacji i marginalizacji osób starszych,

- ograniczenie skutków niepełnosprawności fizycznej,

- aktywizowanie osób starszych do dalszego podejmowania wysiłku w codziennym życiu,

- organizowanie programów działań poświęconych rozwojowi seniorów przez popularyzację interesujących ich zagadnień,

- stworzenie warunków sprzyjających samorealizacji,

- mobilizacja środowiska lokalnego do współdziałania na rzecz seniorów, a także działań podejmowanych przez seniorów na rzecz środowiska lokalnego,

W praktyce podstawowa zmiana to sposób rozliczania domu (własna księgowość), nazwa stanowiska osoby zarządzającej (z administratora na kierownika) oraz wyposażenie. Główny cel oraz funkcje pozostały takie same.

${ }^{18} \mathrm{http}: / / w w w . m o p s . l o d z . p 1 /$ index.php/dzienny-dom-senior-wigor [dostęp: 18.02.2016].

${ }^{19}$ Uchwała nr XX/462/15 Rady Miejskiej w Łodzi z dnia 18 listopada 2015 r. w sprawie wyodrębnienia Domu Dziennego Pobytu w Łodzi przy ul. Sentaroskiej 4 działającego w strukturze MOPS w Łodzi, przekształcenia go i utworzenia Dziennego Domu „Senior-Wigor” w Łodzi i nadania statusu jednostce.

${ }^{20}$ Na podstawie Regulaminu Organizacyjnego Domu Dziennego Pobytu w Łodzi. 


\section{Badanie ankietowe}

W celu odpowiedzenia na pytanie, jakie jest zapotrzebowanie i stopień dostępności do domów dziennego pobytu oraz jaki jest stopień zaspokajania potrzeb i oczekiwań osób do nich uczęszczających przeprowadzono ankietę w 6 domach wśród 96 pensjonariuszy (około 11,5\% spośród wszystkich osób uczęszczających do DDP).

W badaniu udział wzięło 77 kobiet (80\%) i 19 mężczyzn (20\%). Dysproporcja ta wynika $\mathrm{z}$ faktu, że zdecydowana większość pensjonariuszy to kobiety. Ponad połowa ankietowanych (51 osób, co stanowiło $53,2 \%$ badanej próby) to osoby w wieku od 71 do 80 lat, $27 \%$ to osoby w wieku powyżej 80 lat i 19,8\% od 61 do 70 lat. 41 ankietowanych $(42,8 \%)$ to osoby ze średnim wykształceniem, $21(21,8 \%)$ z podstawowym, $18(18,8 \%)$ z zawodowym i $16(16,6 \%)$ z wyższym. $32,5 \%$ ankietowanych jako ostatnie stanowisko pracy wskazało - pracownik umysłowy, 27,5\% - pracownik fizyczny, a 40\% uchyliło się od odpowiedzi.

Na pytanie „Skąd dowiedziała się Pan/Pani o możliwości uczęszczania do domu dziennego pobytu?" najwięcej osób, bo 49\%, wskazało „od osoby znajomej”, 36,5\% „od członka rodziny”, 5,3\% „z Miejskiego Ośrodka Pomocy Społecznej”, $3,2 \%$,od lekarza pierwszego kontaktu”, $2 \%$,z pracy” oraz po $1 \%$ dla odpowiedzi: „,internet”, „telewizja”, „kościół” oraz „Uniwersytet Trzeciego Wieku”.

Dla większości ankietowanych (90 osób, co stanowiło 93,7\% badanej próby) formalności, których należało dopełnić, aby dostać się do domu dziennego pobytu nie były skomplikowane i nie było ich zbyt wiele.

Wykres 1 przedstawia okres, jaki ankietowani musieli czekać po złożeniu wniosku, aby dostać się do domu dziennego pobytu. $40 \%$ osób czekało od 13 do 30 dni, $25 \%$ do 12 dni, $19 \%$ od 1 do 3 miesięcy, $7 \%$ od 6 do 12 miesięcy, $5 \%$ od 3 do 6 miesięcy i $4 \%$ powyżej roku. 


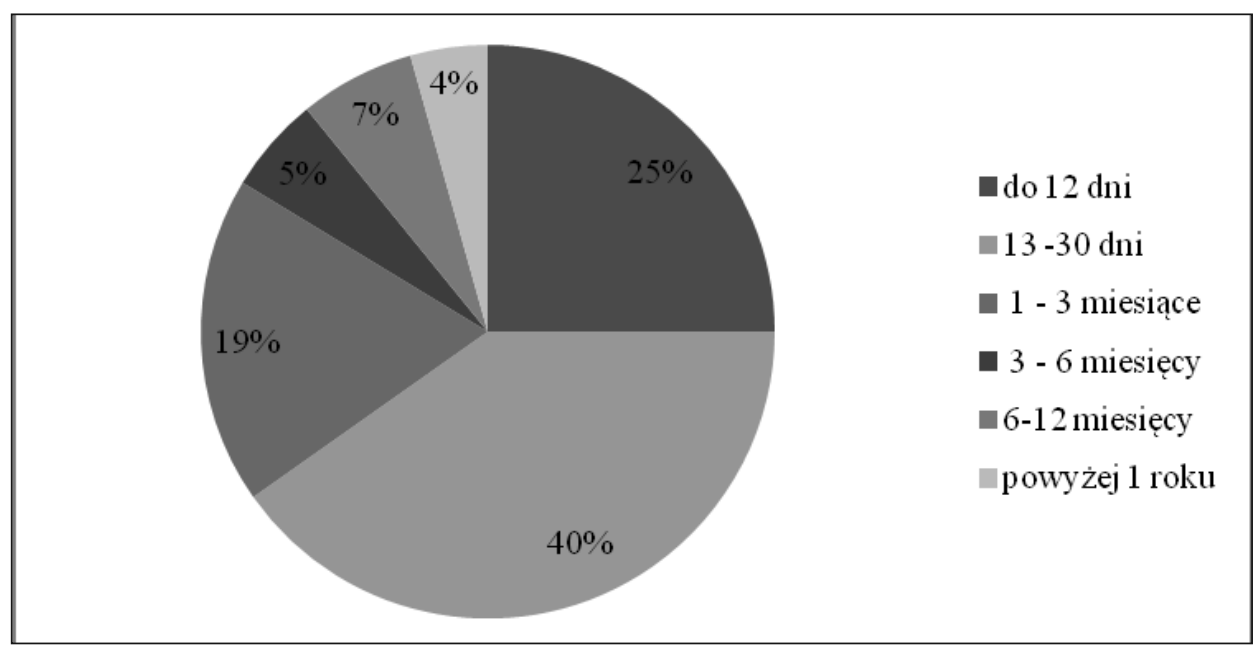

Wykres 1. Czas oczekiwania na przyjęcie do DDP

Źródło: opracowanie własne na podstawie badania ankietowego.

Jak wynika z wykresu 2, 47\% ankietowanych jako najważniejszy powód uczęszczania do domu dziennego pobytu wskazało wyżywienie, 28\% możliwość spotkania z innymi (samotność), 19\% możliwość uczestnictwa w zajęciach zorganizowanych poza DDP (wycieczki, wyjścia do kina i teatru), najmniej osób, bo $6 \%$, zaznaczyło „zorganizowany czas wolny na terenie DDP”.

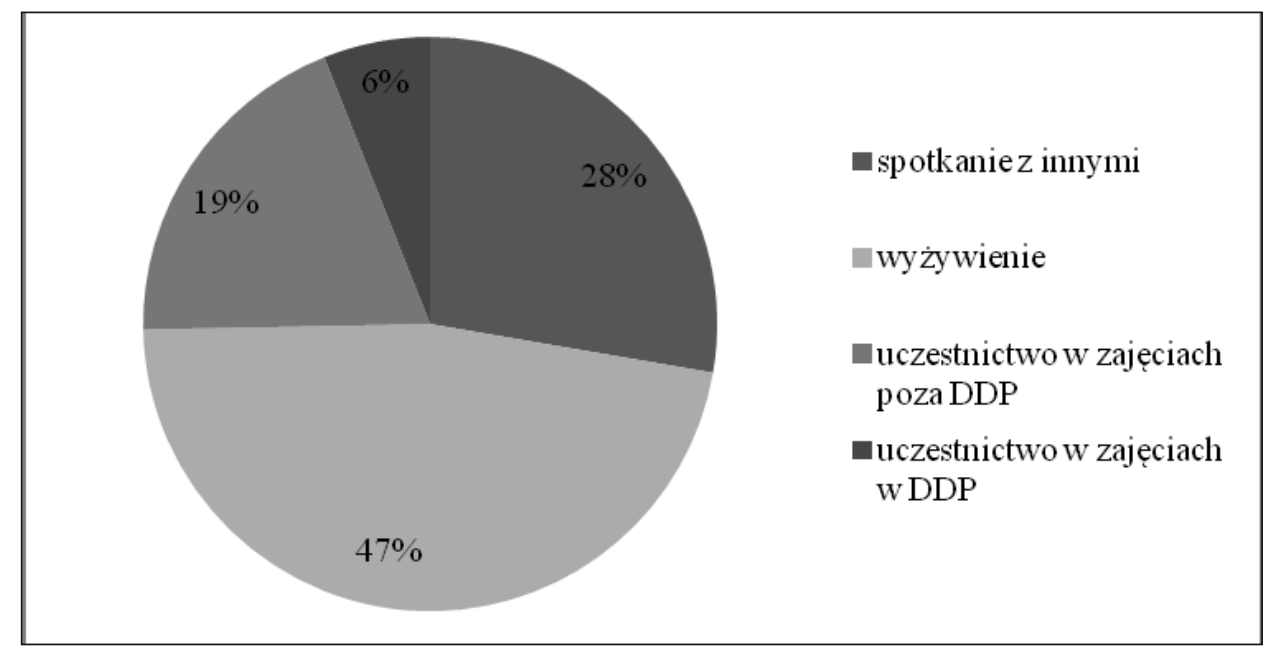

Wykres 2. Główny powód uczęszczania do DDP

Źródło: opracowanie własne na podstawie badania ankietowego. 
Wykres 3 prezentuje liczbę ankietowanych, którzy korzystają z poszczególnych zajęć organizowanych przez DDP. Najwięcej osób (73) uczęszcza na występy zorganizowane poza placówką. Kolejnymi najczęściej zaznaczanymi odpowiedziami były: „wycieczki do innego miasta”, „występy organizowane na terenie DDP” oraz „zajęcia muzyczne”. Najmniej osób korzysta z zajęć plastycznych (39) i zajęć w zorganizowanych w bibliotece publicznej.

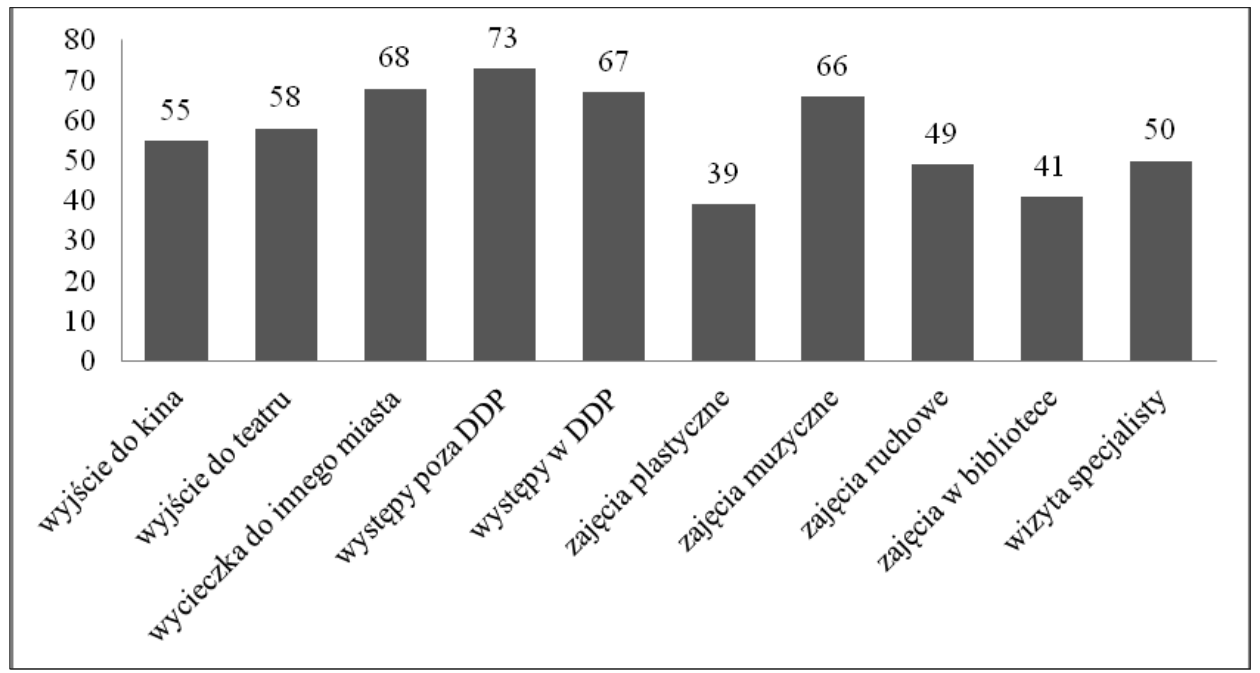

Wykres 3. Liczba osób korzystających z zajęć organizowanych przez DDP

Źródło: opracowanie własne na podstawie badania ankietowego.

Ankietowani zapytani, z jakich organizowanych imprez okolicznościowych korzystają najczęściej, wskazali święta Wielkiej Nocy (90,5\%), nieco mniej osób zaznaczyło dzień seniora (89,5\%), następnie ostatki (87,5\%), karnawał (84\%), Boże Narodzenie (84\%) oraz urodziny lub imieniny pensjonariusza (83\%).

Sprzętami, z których korzysta najwięcej pensjonariuszy, są: ciśnieniomierz (87,5\% odpowiedzi) oraz telewizor i komputer z internetem ( $84 \%$ osób wskazało te sprzęty). Następnie wskazywanymi odpowiedziami były: biblioteczka (78\%), fotel z masażem (60\%), instrumenty muzyczne (55\%), sprzęt rehabilitacyjny (typu rowerek, $45 \%)$ oraz przybory plastyczne $(40 \%)$.

Dla większości (84\%) ankietowanych liczba zajęć organizowanych przez dom dziennego pobytu jest wystarczająca, dla pozostałych $8 \%$ jest niewystarczająca, dla 1\% zbyt duża, $7 \%$ osób nie ma natomiast zdania na ten temat. Również większość pensjonariuszy twierdzi, że zajęcia organizowane przez DDP odpowiadają ich potrzebom, tylko 11,5\% odpowiedzi było negatywnych. 


\section{Wnioski}

Głównym wskazywanym powodem uczęszczania do DDP jest zapewnione wyżywienie. Jednak sumując procenty pozostałych trzech możliwych odpowiedzi, można zauważyć, że większość ankietowanych chce korzystać z DDP w celu socjalizacji. W komentarzach do ankiety pensjonariusze podkreślali, że dzięki opisywanej instytucji nie czują się samotni i bardzo cenią sobie pomoc oferowaną przez jej pracowników.

Jak wynika z przeprowadzonego badania ankietowego, chętne osoby nie muszą długo czekać na możliwość korzystania z domów dziennego pobytu w Łodzi. Dla większości ankietowanych czas oczekiwania wynosił do miesiąca. Liczba miejsc jest ograniczona, jednak podczas wywiadu pracownik MOPS zaznaczył, że w miarę potrzeb i możliwości jest ona powiększana.

Różnorodność i duża liczba zajęć organizowanych w domu dziennego pobytu i poza nim dla zdecydowanej większości jest wystarczająca, a forma odpowiada potrzebom pensjonariuszy.

Dom dziennego pobytu nie jest obowiązkową formą pomocy, dlatego uzyskane wyniki badań mogą nie być zaskakujące. Jednak weryfikują one ich funkcjonalność, która jest zgodna z ustawą o pomocy społecznej, oraz podkreślają znaczenie opisywanej instytucji, pomagającej osobom starszym w codziennym życiu, zapobiegającej poczuciu bezużyteczności i wykluczenia społecznego.

\section{Bibliografia}

Antosz A., Wasiak M., Kierownicy Domów Dziennego Pobytu, [w:] Aktywizacja osób starszych w województwie łódzkim, Regionalne Centrum Polityki Społecznej, PAG-Uniconsult, Łódź 2011.

http://www.mops.lodz.pl/index.php/dzienny-dom-senior-wigor [dostęp: 18.02.2016].

Kruk A.M., Instytucje społeczne. Organizacja, zarzadzanie, wybrane aspekty prawne i gospodarcze, Wydawnictwo Akademii Pedagogiki Specjalnej, Warszawa 2010.

Rozporządzenie Ministra Pracy i Polityki Społecznej z dnia 23 sierpnia 2012 r. w sprawie domów pomocy społecznej (Dz.U. z 2012 r., poz. 964).

Szukalski P., Starzenie się ludności Łodzi i województwa łódzkiego w nadchodzących dekadach, [w:] Aktywizacja osób starszych w województwie łódzkim, Regionalne Centrum Polityki Społecznej, PAG-Uniconsult, Łódź 2011.

Uchwała nr XX/462/15 Rady Miejskiej w Łodzi z dnia 18 listopada 2015 r. w sprawie wyodrębnienia Domu Dziennego Pobytu w Łodzi przy ul. Sentaroskiej 4 działającego w strukturze MOPS w Łodzi, przekształcenia go i utworzenia Dziennego Domu „Senior - Wigor” w Łodzi i nadania statusu jednostce.

Ustawa z dnia 8 marca 1990 r. o samorządzie terytorialnym, Dz.U. nr 16, poz. 95.

Ustawy z dnia 19 sierpnia 1994 r. o ochronie zdrowia psychicznego (Dz.U. z 2011 r. Nr 231, poz. 1375 z późn. zm.).

Ustawa z dnia 12 marca 2004 r. o pomocy społecznej (tj.: Dz.U. z 2013 r., poz. 182 z późn. zm.). 


\section{Streszczenie}

Jedną z form pomocy państwa dla osób starszych są Domy Pomocy Społecznej, które świadczą usługi bytowe, opiekuńcze, wspomagające i edukacyjne. Te placówki, które zapewniają tylko opiekę dzienną nazywają się Domami Dziennego Pobytu (DDP).

Zadaniem niniejszego artykułu jest określenie zapotrzebowania i stopnia dostępności Domów Dziennego Pobytu, stopnia zaspokajania potrzeb i oczekiwań osób do nich uczęszczających oraz przedstawienie zasad ich finansowania. W tym celu przeprowadzono indywidualny wywiad pogłębiony z pracownikiem Miejskiego Ośrodka Pomocy Społecznej w Łodzi zatrudnionym na stanowisku Starszego Inspektora (Dział Planowania) oraz ankietę wśród 96 pensjonariuszy Domów Dziennego Pobytu w Łodzi.

Jak wynika z przeprowadzonego badania ankietowego chętne osoby nie muszą długo czekać na możliwość korzystania z Domów Dziennego Pobytu w Łodzi.

Badanie sprawdza funkcjonalność opisanej instytucji, która jest zgodna z ustawą o pomocy społecznej. Podkreśla ono również znaczenie instytucji w pomocy osobom starszym w życiu codziennym, zapobieganiu poczucia bezużyteczności i wykluczenia społecznego.

Słowa kluczowe: pomoc społeczna, placówki opieki społecznej

Numer klasyfikacji JEL: E02 